\title{
Jacob Burckhardt a antropologický pojem kultury jako výraz historického konzervatismu
}

\author{
Ivo Budil \\ Metropolitní univerzita Praha, Dubečská 900/10, 10031 Praha 10 - Strašnice, e-mail: ivo.budil@mup.cz. \\ Do redakce doručeno 27. listopadu 2020; k publikaci přijato 6. dubna 2021

\section{JACOB BURCKHARDT AND THE ANTHROPOLOGICAL CONCEPT OF CULTURE AS EXPRESSION OF HISTORICAL CONSERVATISM}

\begin{abstract}
The category of culture has established itself in the Anglo-Saxon world in the works of classical evolutionism in anthropology by Edward Burnett Tylor, John Lubbock or Lewis Henry Morgan as a key tool for studying and understanding human difference and diversity, emancipating Western anthropological and historical thought from racial concept. These authors were intellectually linked to the legacy of the Scottish Enlightenment, represented by Adam Ferguson, John Millar or William Robertson, who understood human history as a progressive sequence of universal phases leading to the highest moral and material stage in the form of civilization. Against this combination of Scottish Enlightenment progressivism and anthropological instrumentalization of culture, however, one can oppose the original German definition of culture, which was associated with a conservative response to the Enlightenment and was closer to contemporary anthropological and historical sciences, free from the ethnocentric and ideological prejudices. This interpretation of culture reflecting conservative historical pessimism and concerns about the further development of Western society can be demonstrated in the person and work of the great Swiss historian Jacob Burckhardt, whose Renaissance Culture in Italy marked not only a breakthrough in the study of the Renaissance but also an important inspiration in the emergence of modern cultural history and historical anthropology.
\end{abstract}

KEY WORDS Culture; Jacob Burckhardt; Basel; conservatism; liberalism; Ernst Peter von Lasaulx; Friedrich Nietzsche; Renaissance; Karl Ludwig von Haller

\begin{abstract}
ABSTRAKT Kategorie kultury se prosadila v anglosaském světě v dílech představitelů klasického evolucionismu v antropologii Edwarda Burnetta Tylora, Johna Lubbocka nebo Lewise Henryho Morgana jako klíčový nástroj studia a porozumění lidské odlišnosti a rozmanitosti, který umožňoval emancipovat západní antropologického a historického myšlení od rasového konceptu. Zmínění autoři intelektuálně navazovali na odkaz představitelů skotského osvícenství, Adama Fergusona, Johna Millara nebo Williama Robertsona, kteří chápali dějiny lidstva jako progresivní sled univerzálních fází směřujících k dosažení nejvyššího morálního a materiálního stádia v podobě civilizace (Budil 2003, 85-89). Vưči této kombinaci skotského osvícenského progresivismu a antropologické instrumentalizace kultury lze nicméně postavit původní německé vymezení pojmu kultury, které je spjato s konzervativní reakcí na osvícenství a jež je bližší současným antropologickým a historickým vědám, které se oprostily od etnocentrického a ideologicky zatíženého pojetí univerzálního pokroku zosobněného západní civilizací. Tuto interpretaci kultury odrážející konzervativní historický pesimismus a obavy z dalšího vývoje západní společnosti lze ukázat na osobě a díle velkého švýcarského historika Jacoba Burckhardta, jehož Kultura renesance v Itálii, znamenala nejenom průlom ve studiu renesance, ale také důležitou inspiraci při zrodu moderního studia kulturních dějin a historické antropologie.
\end{abstract}

KLÍČOVÁ SLOVA Kultura; Jacob Burckhardt; Basilej; konzervatismus; liberalismus; Ernst Peter von Lasaulx; Friedrich Nietzsche; renesance; Karl Ludwig von Haller

Alan S. Kahan začlenil Jacoba Burckhardta mezi přední představitele takzvaného aristokratického liberalismu. Kromě něj sem náleželi např́klad John Stuart Mill, Alexis de Tocqueville, lord Acton, Walter Bagehot, Gustave Flaubert nebo George Eliot (Kahan 1992, 4). Aristokratičtí liberálové nepocházeli nutně z urozených rodin, i když mnozí z nich se pyšnili urozeným původem. Spojovala je nedůvěra $\mathrm{k}$ masové demokracii a obava $\mathrm{z}$ expanze státní moci. $\mathrm{S}$ podezřívavostí hleděli na podnikatelského ducha moderní éry a s ním souvisejícím třídním bojem. Někteř́i $\mathrm{z}$ nich dokázali předvídat hrozby to- 


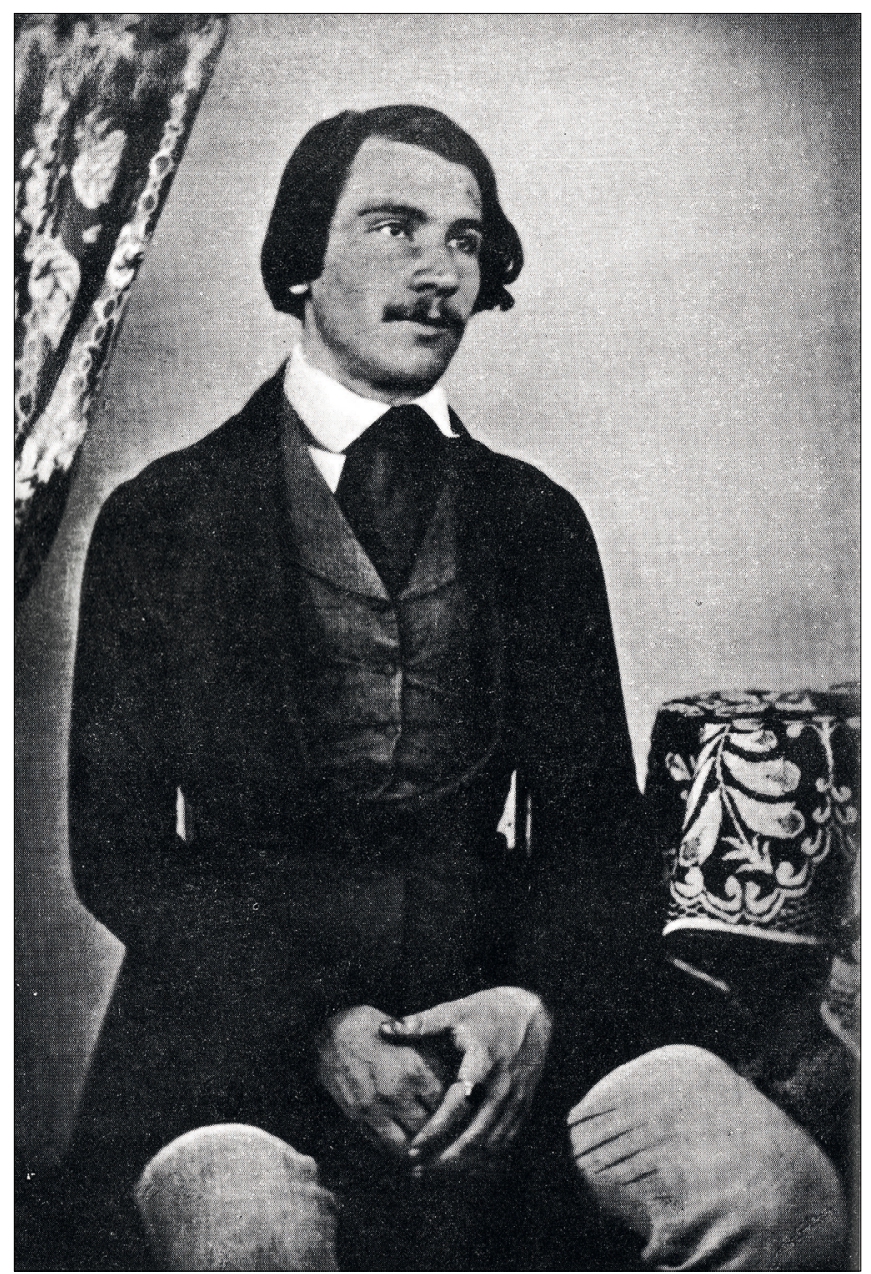

Obr. 1. Jacob Burckhardt. Zdroj: https://cs.wikipedia.org/wiki/Jacob_ Burckhardt\#/media/Soubor:Burckhardt.JPG

talitních a autoritářských režimů v následujícím století. Nebyli konzervativními nostalgiky. Uvědomovali si, že návrat $\mathrm{k}$ ancien régime je nemožný, a veškeré snahy $\mathrm{v}$ tomto smyslu pokládali i za nežádoucí. Jejich vztah k odkazu osvícenství byl ambivalentní. Těžili z osvícenských hodnot, ale univerzalistické aspirace osvícenského racionalismu zmírňovali historicismem, odkazem $\mathrm{k}$ důležitosti historického kontextu a jedinečnosti. Jejich světonázor se do značné míry zrodil jako výraz diskuse mezi klasickými liberály a konzervativními stoupenci restaurace v letech 1815 až 1830. Aristokratičtí liberálové nesdíleli whigovský progresivistický pohled na dějiny. Nepodlehli nicméně ani fatalistickému historickému pesimismu, čímž se odlišovali od Arthura Gobineaua nebo Oswalda Spenglera. Studium historické imaginace předních reprezentantů aristokratického liberalismu je důležité, protože se dotýká otázky, zda můžeme v intelektuálním odkazu aristokratického liberalismu nalézt přesvědčivé prostř̌edky $\mathrm{k}$ překonání krize soudobého liberalismu.

Aristokratičtí liberálové pokládali osmnácté století, a především Francouzskou revoluci, za dobu zrodu modernity. Státní centralizace, komercionalizace a expanze střední třídy ohrožovaly hodnoty, jichž si nejvíce cenili a které zahrnova- ly svobodu, individualitu a kulturní rozmanitost. Na rozdíl od klasických liberálů představovaly pro aristokratické liberály francouzské dějiny, nikoliv dějiny Anglie, archetyp či pravzor zrodu moderní společnosti. Anglii vnímali jako izolovanou jednotku oddělenou od kontinentu, s jehož dynamikou byla občas v souladu, ale často za ní zaostávala. Dokonce John Stuart Mill pokládal francouzskou civilizaci za nejbližší normálnímu typu lidské společnosti, která přináší pro historiky nejvíce poučení, zatímco anglické dějiny označil za naprosto nezajímavé (Kahan 1992, 11-12).

\section{ERNST PETER VON LASAULX}

Lord Acton pokáral v šedesátých letech devatenáctého století anglické vzdělance, že jejich pozornosti unikla tři díla, která $\mathrm{v}$ průběhu uplynulého desetiletí zásadním způsobem ovlivnily filozofii dějin a jež zahrnovala Gobineauovo Pojednání o nerovnosti lidských ras, práce Johanna Christopha Vollgraffa a Filosofie dějin (Philosophie der Geschichte) od Ernsta von Lasaulxe (Engel-Janosi 1953, 377). Každého čtenáře Úvah o světových dějinách od Jacoba Burckhardta zaujme, jak často velký švýcarský historik zmínil Lasaulxovo jméno. Žádnému jinému autorovi se nedostalo takové výsady. Úvahy o světových dějinách vypadají takřka jako dialog mezi Burckhardtem a Lasaulxem.

Ernst Peter von Lasaulx, jeden ze zakladatelů aristokratického liberalismu, je dnes prakticky zapomenut. Je to krajně nespravedlivé, protože od Lasaulxe se odvíjela pozoruhodná intelektuální linie spojující Jacoba Burckhardta s Friedrichem Nietzschem, Oswaldem Spenglerem a Arnoldem Toynbeem. Stephen Tonsor pokládal Ernsta von Lasaulxe za hlavního prostředníka mezi Giambattistou Vicem a Johannem Gottfriedem Herderem na straně jedné a Oswaldem Spenglerem na straně druhé (Tonsor 1964, 374).

Ernst Peter von Lasaulx se narodil v roce 1805 v Koblenzi v Porýní. Lasaulxovým strýcem byl Josef Görres, původně radikální zastánce Francouzské revoluce, který nicméně počátkem dvacátých let devatenáctého století konvertoval ke katolicismu a přešel do konzervativního tábora. Později přednášel historii na Mnichovské univerzitě. Lasaulx studoval v letech 1824 až 1828 na univerzitě v Bonnu klasické dějiny a mytologii pod vedením Bartholda Georga Niebuhra a Carla Theodora Welckera a německou literaturu u Friedricha Schlegela. Lasaulxe obdobně jako většinu německých vzdělanců počátku ovlivnil v oblasti klasických studií Johann Wolfgang Goethe, Johann Joachim Winckelmann nebo Friedrich Wilhelm Joseph Schelling. Dobře znal klasickou práci o vývoji mytologie a symbolismu Georga Friedricha Creuzera. ${ }^{1}$ Studoval středověké mystiky Mistra Eckharta a Jacoba Böhma (Tonsor 1964, 376). Mezi jeho mentory náležel Johann Joseph Ignaz von Döllinger, katolický duchovní, historik a teolog (Tonsor 1964, 375). Lasaulx byl historickým pesimistou. $\mathrm{V}$ osudu římského a řeckého světa viděl obdobu úpadku západní společnosti a její tvořivosti a síly.

1 Symbolik und Mythologie der alten Völker, besonders der Griechen (1810-12). 


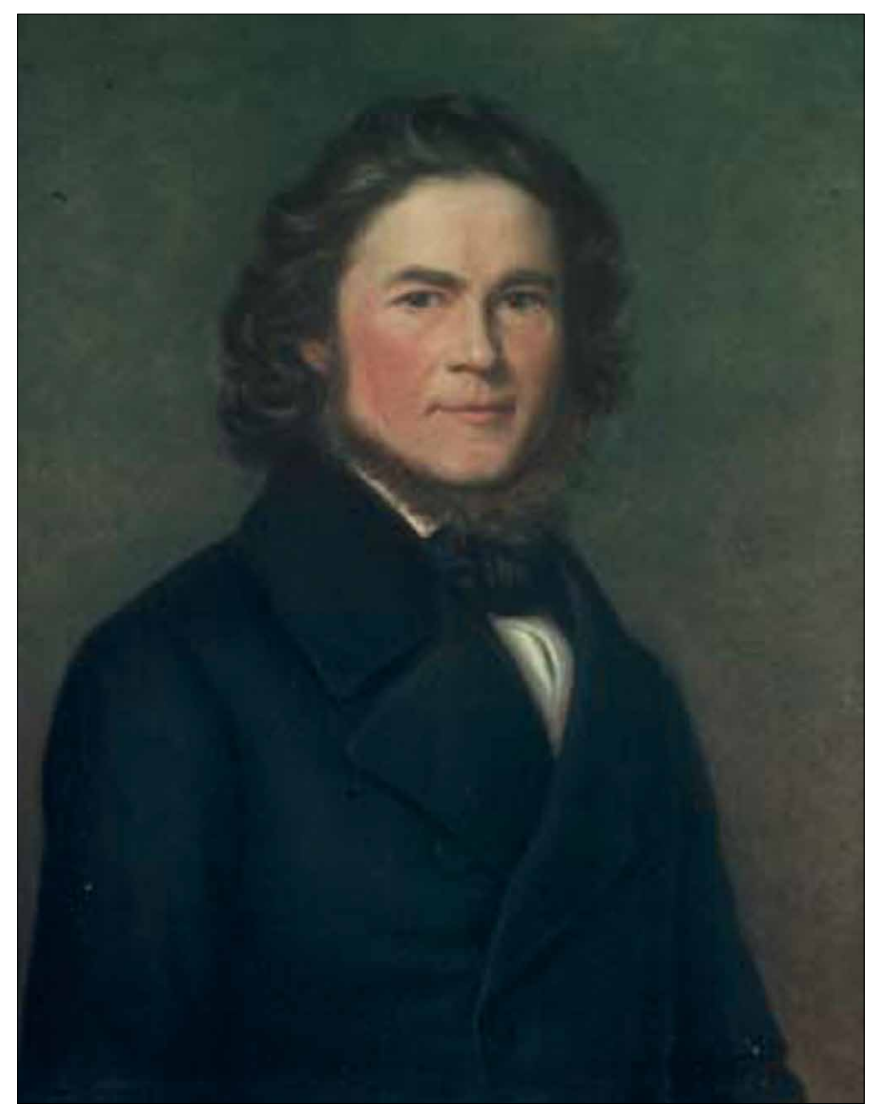

Obr. 2. Ernst Peter von Lasaulx. Zdroj: https://de.wikipedia.org/wiki/Ernst_ von_Lasaulx\#/media/Datei:Lasaulx.jpg

V létě 1830 ještě před složením závěrečných zkoušek zahájil Lasaulx cestu (Wanderjahre) do Rakouska, Itálie, Řecka a Jeruzaléma. Po návratu získal v dubnu 1834 na univerzitě v Kielu doktorát na základě obhajoby disertační práce $D e$ mortis dominatu in veteres, commentatio theologica-philosophica. Poté působil na univerzitě jako profesor klasické filologie ve Würzburgu, kde jeden rok vykonával funkci rektora. V roce 1838 vystoupil Lasaulx na podporu kolínského arcibiskupa, který byl pruskou vládou uvězněn kvůli své obhajobě smíšených sňatků mezi protestanty a katolíky (Engel-Janosi 1953, 377).

Bonn však Lasaulxe neuspokojoval. Odešel v roce 1844 do Mnichova, jehož nově zrrízená univerzita, sponzorovaná bavorským králem Ludvíkem I., aspirovala na postavení jednoho $\mathrm{z}$ nejdůležitějších středisek německé vzdělanosti. Zapojil do politické činnosti. Výsledkem byl měsíc vězení, k němuž byl odsouzen za jeden článek uveřejněný v mnichovských novinách. Ernst von Lasaulx se oženil s Julií, dcerou Franze Xavera Benedicta von Baadera, vlivného katolického a romantického filozofa a teologa, který rovněž od roku 1825 působil na Mnichovské univerzitě (Tonsor 1964, 376). Roku 1847 byl Lasaulx dočasně suspendován z profesorské pozice kvưli svému kritickému postoji v případě aféry Loly Montezové.

Lola Montezová neboli Marie Dolores Rosanna Gilbertová byla irská herečka a zpěvačka, která se stala milenkou Ludvíka I.
Bavorského, jenž z ní učinil vévodkyni z Landsfeldu. Vystupovala na různých evropských scénách a $\mathrm{v}$ Paříži měla krátký poměr s Franzem Lisztem. Během svého pobytu v Mnichově v letech 1846 až 1848 výrazně ovlivnila místní politický život. Lola Montezová zastávala liberální postoje, což jí znepřátelilo konzervativní kruhy, zejména jezuity. V březnu 1848, kdy revoluční výbuch přinutil panovníka abdikovat, Lola Montezová opustila zemi. V následujících letech svého dobrodružného života Lola Montezová působila ve Spojených státech amerických a Austrálii. Její osobnost údajně inspirovala Arthura Conana Doyla k vytvoření postavy Ireny Adlerové v povídce Skandál v Čechách (Seymour 1996).

V průběhu revolučního roku 1848 se Ernst von Lasaulx stal poslancem Frankfurtského parlamentu, na jehož půdě hájil konzervativní názory oproti liberální většině. Nejvyšší Lasaulxovy aspirace však nespočívaly v politické kariéře, ale ve filozofii dějin. Ernst von Lasaulx vyjádřil přání vytvořit „ságu univerzálních dějin“ („die Mär der Weltgeschichte“). Je možné, že ho v tomto směru inspiroval Johann Joseph Görres, který přednášel univerzální dějiny na Mnichovské univerzitě. Lasaulx plně souhlasil se Schellingovým pojetím dějin jako celistvým organismem, jenž postupně uskutečňuje svůj potenciál v čase (Engel-Janosi 1953, 382). Sdílel Vicovo, Görresovo a Schellingovo přesvědčení, že náboženství představuje základ a jádro historie. Zatímco například Georg Wilhelm von Hegel nebo Leopold von Ranke vyzvedávali historickou úlohu náboženství, ale zajímal je především vliv religiozity na politické dění, Johann Joseph Görres a Friedrich Wilhelm Joseph Schelling zaměřili na výzkum lidské duše či nevědomí, které je zdrojem náboženského symbolismu (Engel-Janosi 1953, 383).

Lasaulx, jehož inspirovali středověcí vizionářští mystici jako Jáchym z Fiore nebo jeho žák Gerardus di Borgo San Donnino, v roce 1841 napsal: „Veškerá minulost představuje ve své nejhlubši povaze prototyp, předzvěst budoucnosti, která je jejím cílem. Dějiny jednotlivých národů jsou dílćmi údy jednoho organismu lidstva a nemají než jeden život. Vytvářejí linii, jejiž poslední zástupce shrnuje rysy všech, kteři jej předcházeli“ (Engel-Janosi 1953, 385). Tuto organickou metaforu zděděnou ze středověké mystiky Ernst von Lasaulx spojil s teorií ontogeneze, podle níž ontogenetický vývoj rekapituluje fylogenezi. Zmíněná teorie je nejčastěji spojována se jménem německého darwinisty a embryologa Ernsta Haeckela, nicméně její původ sahá hlouběji do tradice německé Naturphilosophie, prací anatoma a fyziologa Ignaze Döllingera, otce známého teologa a historika, Karla Ernsta von Baera a Karla Friedricha Burdacha. Ernst von Lasaulx byl proto přesvědčen, že jedinec představuje $\mathrm{v}$ průběhu svého života postupné uskutečňování potenciálu svého archetypálního předka (Urmensch). Existuje společný proces či morfologie rozvíjená a sdílená všemi lidmi, kulturami, jazykem, náboženstvím, uměním, vědou, osadou, městem nebo státem, který prožívá mládí, rozkvět a poté, kdy vyčerpal svůj potenciál, umírá. Každá civilizace zná jaro, léto, podzim a zimu. Propojení všech zmíněných údů civilizačního organismu se nazývá Zeitgeist (Tonsor 1964, 383-384). Lasaulxovo univerzální i komparativní pojetí lidských dějin 
bylo v jeho době ojedinělé a anticipovalo pozdější impozantní Spenglerovy a Toynbeeho syntézy.

Vzhledem k tomu, že podle Lasaulxe spočívá veškerá historie ve studiu dějin náboženství, lze pokládat křestanství za světovou univerzální religiozitu, která v sobě obsahuje všechna předchozí náboženství v míre, $v$ níž jsou pravdivá. Stěží nalezneme v křestanství jedinou pravdu, kterou bychom nezaznamenali v předkřestanské ére. $Z$ tohoto důvodu označil Lasaulx Sokrata za skutečného „Kristova předchůdce“ („verus typus Christi“): „Domnívám se, že žádná osobnost Starého zákona neni tak dokonalou anticipací Krista jako Řek Sokrates, a stejně tak nepochybuji, že to nejlepší z křrestanské filozofie je bližši helénismu než judaismu“ (Engel-Janosi 1953, 390). Nebylo pravděpodobně překvapující, že Lasaulxova Filozofie dějin byla katolickou církví v říjnu 1861 zařazena na seznam zakázaných knih (Librorum prohibitorum). Lasaulxův žák lord Acton k jeho postoji poznamenal: „Ferdinand Christian Baur odvodil křestanství z kombinace dvou zdrojů, Izaiáše a Sokrata ... Lasaulx měl obdobný náhled, pokud jde o hloubku, vážnost a význam pohanství, které nepovažoval za chybu či úpadek, ale za dílči stádium vývoje směrujícího $k$ Pravdě, od Hérakleita k Platónovi, od Sofokla k Senekovi a od Zenona k Plutarchovi“ (Tonsor 1964, 380).

Náboženství představovalo podle Lasaulxe rovněž klíč $\mathrm{k}$ pochopení vývoje umění směřujícího ke stále vyšší míře spiritualizace. Nejvíce spjata s hmotou je architektura, následuje sochařství, malířství, hudba, poezie a nakonec próza, nejduchovnější ze všech druhů umělecké tvořivosti (Tonsor 1964, 387-388).

Při studiu historických analogií Ernst von Lasaulx konstatoval, že průběh řeckých a římských dějin v mnohém odpovídal osudům moderního německého národa. Organický vývoj se projevoval v podobných formách vlády. Poznamenal, že pokud by Aristoteles měl prríležitost seznámit se s německými politickými poměry ve čtyřicátých letech devatenáctého století, konstatoval by, že u moci se nachází oligarchie, zatímco démos se chystá převzít vládu (Engel-Janosi 1953, 391). Lze tedy činit historické predikce a prognózy. Obdobně jako v prípadě lidského jedince se národní organismus podléhající stejným zákonitostem vyčerpá v okamžiku, kdy pozbude svůj veškerý historický potenciál (élan vital). Život nikdy nekončí, pouze jeho formy se mění a nové vyrůstají z těch, které odumřely. Lasaulx neváhal se uchýlit $\mathrm{k}$ biologickému idiomu: „Jestliže národ již $v$ době nenese nespotřebovanou prírodní sílu, jeho skon je neodvratitelný. Může být znovu oživen pouze př́livem barbarü“ (cit. Engel-Janosi 1953, 392).

Lasaulxova historická morfologie je odvozena především z Aristotela, Polybia a Vica. Zmíněný historik rozlišil tř̀i „čisté formy politického zřízení, které zahrnovaly monarchii, aristokracii a demokracii, jejichž korupcí vzniká tyranie, oligarchie a anarchie. Monarchie ústí do tyranie, tyranie do aristokracie, aristokracie do oligarchie, oligarchie do demokracie a demokracie do anarchie, po níž následuje vojenská diktatura. Revoluce jsou zdravé a očistné během mládí společnosti, jakmile zestárne, představují obdobu nebezpečné choroby (Tonsor 1964, 388-389). Za nejspolehlivější nástroj poznání minulosti národů považoval Ernst von Lasaulx jazyk a jeho proměny. Na rozdíl od Arthura Gobineaua se nepřiklonil $\mathrm{k}$ deterministickému rasovému výkladu dějin. Přesto se nevyhýbal rasové terminologii, kterou odvodil ze Starého zákona. Pro dějiny lidstva byl podle Lasaulxe příznačný neustávající antagonismus mezi Semity a potomky Japetovy, k nimž náležejí i obyvatelé Německa (Engel-Janosi 1953, 394).

Obdobně jako Georg Wilhelm Hegel ve Filozofii práva Lasaulx byl přesvědčen, že pouze tehdy, když v životě národa nastává večer, objevuje se skutečná filozofie dějin - Minerviny sovy vzlétají za soumraku (Engel-Janosi 1953, 392). Několik desetiletí před Arnoldem Toynbeem Ernst von Lasaulx napsal, že mnohá náboženství se rodí na sklonku života civilizace a předávají její nejvyšší kulturní hodnoty a aspirace jejím nástupcům (Engel-Janosi 1953, 395-396).

Zmíněné úvahy byly zakotveny v cyklickém pojetí dějin, které Ernst von Lasaulx převzal od Platóna a Aristotela a v novější podobě od Giambattisty Vica (Engel-Janosi 1953, 386-387). Zatímco Jáchyma z Fiore, Gerarda di Borgo San Donnino, Friedricha Wilhelma Josepha Schellinga a Ernsta von Lasaulxe můžeme pokládat za historické optimisty, jiní autoři zdůrazňující „,večný návrat“ historických forem jako Giambattista Vico, Arthur Gobineau, Oswald Spengler nebo Brooks Adams sdíleli pesimističtější náhled (Engel-Janosi 1953, 388).

Ernst von Lasaulx převzal od středověkých myslitelů Hugha ze St. Victoire a Oty z Freisingu tezi o postupném přesunu těžiště světových dějin z Východu na Západ, které Johann Jakob Bachofen doplnil tvrzním, že osudový zápas mezi Západem a Východem představuje hlavní téma světové historie (Engel-Janosi 1953, 394). Lasaulx k tomu dodal, že zmíněný konflikt počínající trojskou válkou nebo bitvou u Marathónu pokračuje úspěchy britských zbraní v Indii a Číně, a předpověděl brzké zhroucení Osmanské říše. Lasaulx na rozdíl od většiny představitelů osvícenství souhlasil s Giambattistou Vicem a Josephem de Maistrem, že válka je zdrojem skutečných historických změn: „Válka je božská. Je tvořivá jak v materiálním, tak duchovním smyslu“ (Tonsor 1964, 385). Nikoliv normální a zkrocené, ale abnormální a divoké zakládá nový řád. Ernst von Lasaulx stranil vítězi, v jehož úspěchu viděl př́izeň dějin. Tím se lišil od Arthura Gobineaua, Jacoba Burckhardta nebo Fridricha Nietzscheho, kteří nevěřili, že by se $\mathrm{v}$ moderním světě mohla opět prosadit skutečná velikost a ušlechtilost. Nietzsche prohlásil, že Démosthenés navzdory své prohře dosáhl velikosti. Porážka je důkazem ušlechtilosti, která nemá v době zkaženosti a civilizačního úpadku šanci na úspěch. Chceme-li vidět opravdové osobnosti, podívejme se do řad poražených (Engel-Janosi 1953, 395). Ernst von Lasaulx byl přesvědčen, že válka, která je zdrojem opravdové velikosti, je stále možná. Pokles válečné výkonnosti pokládal za projev národního úpadku (Tonsor 1964, 385).

V jakém stádiu svého historického cyklu se nacházela podle Lasaulxe soudobá Evropa? Zatímco buddhismus a judaismus se bezpochyby nalézaly za zenitem, týkalo se to rovněž křestanství? Lasaulx uznal, že vitalita románsko-germánských národů klesá bez naděje na zvrat. To by však nemuselo znamenat konec našeho kontinentu, kterému mohou dodat čerstvou 


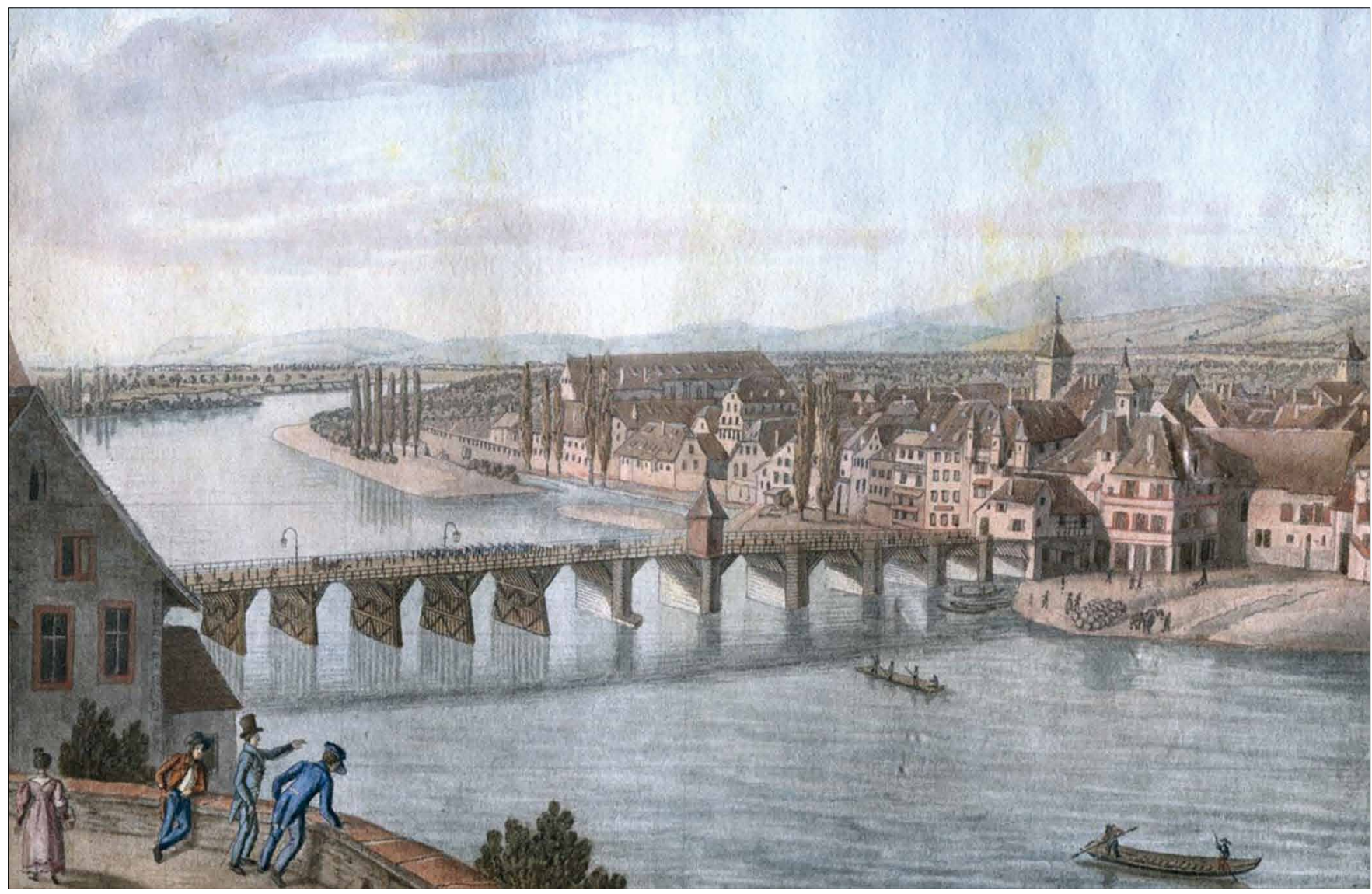

Obr. 3. Basilej v devatenáctém století. Zdroj: https://www.sulisfineart.com/historical-mid-19th-century-lithograph-view-of-basel-basle-switzerland.html

energii mladá a silná slovanská etnika. V tomto smyslu se Ernst von Lasaulx vyjádřil rovněž na půdě bavorského sněmu. Jako zastánce „velkoněmeckého“ ř̀ešení (Grossdeutsch) doufal, že ve sjednoceném Německu, které zahrne rovněž Rakousko, povede německý intelekt a slovanská vitalita k žádoucí obnově. Lasaulxovo mínění sdíleli Adam Mickiewicz, Donoso Cortes nebo Franz Grillparzer (Engel-Janosi 1953, 399). Po roce 1856 dospěl stárnoucí Lasaulx k závěru, že západní civilizaci již nelze zachránit. Vykazuje stejné známky rozkladu jako antika na počátku temného věku: „Patřím $k$ těm, kteři nevěři $v$ politickou restauraci. Žádná taková věc neexistuje. Všechny obnovy, o něž se lidé pokusili, skončily za krátkou dobu neúspěchem ... Není cesty zpátky. Brány jsou zavřeny. Mosty jsou zbořeny. Lodě jsou spáleny. Historie velí kupredu, i kdybychom méli pochodovat do záhuby“ (Tonsor 1964, 389).

Když Ernst von Lasaulx počátkem května 1861 v Mnichově předčasně zemřel, bylo Jacobu Burckhardtovi třiačtyřicet let. Teprve připravoval svůj první rozsáhlejší spis. Pocházel ze švýcarské Basileje, kde se narodil v roce $1818 \mathrm{v}$ rodině pastora $\mathrm{v}$ domě poblíž katedrály. ${ }^{2}$ Mezi jeho předky náleželo jedenáct

2 Osmisvazkové dílo věnované Jacobu Burckhardtovi vydával v letech 1947 až 1982 Werner Kaegi, manžel proslulé katolické mystičky Adrienne von Speyer, jejímž mentorem byl teolog Hans Urs von Balthasar. radních, zámožnější obchodníci či profesoři na místní univerzitě, nejstarší ve Švýcarsku (Hinde 2000, 44). ${ }^{3}$ Bylo to sociální prostředí vzdělané střední měštanské třrídy (Bildungsburgertum).

\section{NĚMECKÝ LIBERALISMUS A KONZERVATISMUS V PRVNÍ POLOVINĚ DEVATENÁCTÉHO STOLETÍ}

V Basileji se údajně nacházely městské hodiny, které ukazovaly vždy o jednu hodinu méně než zbytek Evropy. Když do města přišly v roce 1798 francouzské revoluční jednotky, sladily čas se zbytkem kontinentu. Po pádu Napoleona byl tento nehorázný průnik progresivismu odstraněn a na hodinách byl opět nastaven „správný“ basilejský čas. Napoleona Bonaparta veřejně pozval do Basileje místní osvícenec Peter Ochs, který jej vyzval, aby svrhl zdejší ancien régime. Ochs dokonce vypracoval ústavu La Republique Helvetique, une et indivisible inspirovanou ideály Francouzské revoluce (Hinde 2000, 38). Basilej bylo zámožné město. Na počátku devatenáctého století zde obdobně jako v uplynulých staletích stále vládly bohaté patricijské rodiny (marchands-fabricants-banquiers). S politickým a hodnotovým konzervatismem kontrastoval dynamismus basilejských finančníků a podnikatelů.

3 Založil ji v roce 1460 papež Pius II. (Aeneas Silvius Piccolomini). 
Basilejský kapitál, který byl soustředěn v šestnácti bankovních domech, proudil nejen do Švýcarska, ale rovněž do Německa a Francie, či dokonce do New Orleans a Sydney (Hinde 2000, 47).

Burckhardt přišel na svět ve zdánlivé politické a ideologické nehybnosti restaurační éry (Herman 1997, 76-77). Časy se záhy změnily, a to jak $\mathrm{v}$ politické, tak intelektuální sféře. Revoluční události roku 1830 se nevyhnuly ani pětadvacetitisícové Basileji. Švýcarští liberálové usilovali o vyhlášení švýcarské národní jednoty (Volk), která by nahradila tradiční kantonální patriotismus (Kantonligeist). V roce 1833 se od basilejského kantonu oddělily venkovské oblasti (Kantonstrennung) a vytvořily dva nové částečně autonomní kantony (Basel-Stadt a Basel-Landschaft). Byla to nejvážnější krize od náboženských válek a zároveň předzvěst občanské války v listopadu 1847 (Sonderbundkrieg).

V roce 1836 zahájil Jacob Burckhardt studia teologie na Basilejské univerzitě. Mezi jeho učitele náleželi dva přední teologové Wilhelm de Wette a Karl Rudolf Hagenbach. V té době kritická biblická studia zpochybnila autenticitu Starého a Nového zákona. David Strauss vydal roku 1835 „obrazoboreckou“ knihu Život Ježišioiv, která otřásla vírou mnoha Evropanů. Náležel mezi ně rovněž Jacob Burckhardt, který se vzdal úmyslu stát se duchovním a pokračovat $\mathrm{v}$ rodinné tradici, jež mu byla původně určena. Po rezignaci na dráhu pastora odjel Burckhardt v záŕí 1839 do Berlína, kde se hodlal věnovat se historii.

Podle řady autorů došlo $\mathrm{v}$ německých historických vědách na přelomu osmnáctého a devatenáctého století k zásadnímu přelomu, který Karl Mannheim charakterizoval jako přechod od „statické filozofie rozumu“ charakteristické pro osvícenství k „dynamické historické filozofii života“, která se později uplatnila např́klad rasových vizích dějin nebo darwinismu. Zrodil se historicismus, jak daný směr nazval Friedrich Meinecke. ${ }^{4}$ Prosadil se názor, že veškeré lidské hodnoty a ideje jsou jedinečné a kulturně podmíněny. Neexistuje žádná realita nebo význam, který by unikal proudu historického času. Pokrok je pouhá iluze. Každá epocha musí být posuzována na základě svých vlastních hodnot. Významný vliv na formování historicismu měl bezpochyby Giambattista Vico nebo Johann Gottfried Herder. Někteří autoři jako Ernst Troeltsch označili historicismus za největší německý příspěvek západnímu myšlení od časů reformace a nejvyšší dosažené stádium v porozumění problematice člověka a společnosti (Hinde 2000, 142-144). ${ }^{5}$

Donald R. Kelley byl nicméně přesvědčen, že historicismus spočívající v obratu od obecného k partikulárnímu a typického k jedinečnému nebyl výlučně produktem německé osvobozovací války proti Napoleonovi (Freiheitskriege), ale že šlo o trend prosazující se v celém západním historickém myšlení. Jeho projevy odhalil Donald R. Kelley již v dílech renesančních humanistů. Německý historicismus tak údajně nebyl

\footnotetext{
4 Die Entstehung des Historismus (1936).

5 Především tzv. bielefeldská škola vyzvedávala vědecký ráz historismu a osvícenskou historiografii pokládala za "předvědeckou“.
}

inovací, ale spíše specifickým sladěním německé vzdělanosti s evropským intelektuálním prostředím. Němečtí badatelé přispěli především vymezením rigoróznějších postupů a metody historické práce včetně její profesionalizace a jednoznačným akademickým ukotvením (Hinde 2000, 148). Německá historiografická škola na rozdíl od francouzského nebo anglického prostředí zavrhla nomotetický a pozitivistický přístup Augusta Comta nebo Thomase Henryho Buckleye a trvala na tom, že př́rodovědné metody nelze uplatnit př́i historickém studiu. Namísto toho němečtí autoři, např́klad Johann Gustav Droysen, upřednostňovali hermeneutiku a kritickou metodu pramenů přejaté $\mathrm{z}$ tradice klasické filologie. Důležitý rozdíl mezi osvícenskou historiografií a historickými pracemi z počátku devatenáctého století spočíval v potlačení literární, rétorické složky textu ve prospěch strohého „vědecky objektivního“ jazyka. Historikové s literárními sklony začali být podezřelí a na této skutečnosti se až doposud nic nezměnilo (Hinde 2000, 155).

S výjimkou letního semestru 1841, který strávil v Bonnu, byl Jacob Burckhardt několik let posluchačem Berlínské univerzity (Burckhardt 1995, 237). Zmíněná vysokoškolská instituce vznikla $\mathrm{v}$ roce $1810 \mathrm{z}$ podnětu Wilhelma von Humboldta jako součást rozsáhlých administrativních reforem pruského státu po jeho drtivé porážce Napoleonem Bonapartem. Prvnímu rektorovi, jímž byl Johann Gottlieb Fichte, se podařilo vybudovat výkonné centrum moderní vzdělanosti, na kterém působili například Georg Wilhelm Friedrich Hegel, Friedrich Karl von Savigny, Karl Friedrich Eichhorn, Friedrich Schleiermacher, a Bartold Georg Niebuhr. Jacob Burckhardt navštěvoval především přednášky Theodora Droysena, Augusta Böckha, a zejména Leopolda von Rankeho. ${ }^{6}$ Franz Theodor Kugler jej zasvětil do dějin umění a architektury (Hinde 2000, 71).

Jacob Burckhardt kolísal během studií mezi konzervatismem, který byl takř̀ka oficiální ideologií sílícího pruského státu, a liberalismem, k němuž se hlásila opozice. Mezi čelné představitele pruského konzervatismu náležel Burckhardtův oblíbený učitel Leopold von Ranke. Zatímco Theodor Droysen a Georg Wilhelm Friedrich Hegel věřili, že vrcholem západních dějin je národní stát zaštitující lidskou svobodu, Leopold von Ranke byl k myšlence pokroku a historických zákonitostí podstatně skeptičtější. Hegelovu filozofii dějin odmítal. Historik by se měl podle jeho mínění zabývat individuálními aktéry, nikoliv zabředávat do obecných a abstraktních spekulací (Hinde 2000, 160). Za hlavní historikův úkol považoval Ranke zjistit prostřednictvím důkladného historického studia, ,jak to opravdu bylo“ („wie es eigentlich gewesen ist“). Úvahy o povaze dějin jako takových nicméně zcela nezavrhoval. Byl přesvědčen, že v dějinách existují duchovní a tvořivé síly a morální energie. $\mathrm{V}$ jejich vzestupu, úpadku a obrození spočívá tajemství dějin, přičemž nejvýrazněji se zmíněné síly projevují v politickém životě (Herman 1997, 79). Zrod národních států v raném no-

6 Friedrich Meinecke neváhal po druhé světové válce označit Leopolda von Rankeho a Jacoba Burckhardta za největší historiky německé jazykové oblasti (Kahan 1992, 7). 
vověku představoval podle Rankeho proměnu středověkého univerzalismu v moderní partikularismus (Sax 1992, 845847). Jak upozornil Ernst Gombrich, Jacob Burckhardt byl na rozdíl od Rankeho ovlivněn Hegelovou filozofí, jak o tom svědčí jeho práce o italské renesanci (Gombrich 1969, 6).

Obdobně jako v jiných evropských zemích bylo období mezi lety 1815 až 1830 ve znamení konzervativní reakce na předchozí epochu Francouzské revoluce a napoleonských válek. Termín „restaurace“, který se v této souvislosti používá, je odvozeno z názvu díla Karla Ludwiga von Hallera Restauration der Staats-Wissenschaft oder Theorie des natürlich-geselligen Zustandes, der Chimäre des künstlich-bürgerlichen entgegengesetzt, které vycházelo v letech 1816 až 1834. Hlavními „ideology“ restaurace byli kromě Hallera především Edmund Burke v Anglii a Louis de Bonald a Joseph de Maistre ve Francii. V německo-jazyčných zemích probíhala restaurace ve znamení romantického fascinace středověkem jako „zlatého věku“ Západu v dílech Wilhelma Heinricha Wackenrodera nebo Novalise. Němečtí romantici jako například Adam Müller snili o obnově Svaté říše rrímské evropských národů sjednocených na základě znovuoživeného křestanství (Liedke 1958, 371).

\section{KARL LUDWIG VON HALLER}

Dnes poněkud polozapomenutý Karl Ludwig von Haller byl jednou $\mathrm{z}$ nejvlivnějších a nejdiskutovanějších osobností prvních desetiletí devatenáctého století. Narodil se v roce 1768 v Bernu a již v mládí prokazoval mimořádné nadání. V šestnácti letech pracoval pro státní kancléřství. Vždy se chlubil, že jeho intelekt nikdy nepokřivilo žádné univerzitní vzdělání. Jako zástupce Bernu uskutečnil diplomatické mise do jižního Německa, Milána a Paříže. Seznámil se s Napoleonem, Talleyrandem a Metternichem. Po vyhlášení Helvétské republiky v roce 1798 francouzské revoluční jednotky obsadily Bern. Haller odešel do Vídně, kde působil v rakouských službách. Do Bernu se vrátil roku 1806. Přednášel právo na místní akademii. Výmluvně obhajoval středověký feudální společenský řád a argumentoval, že ve společnosti platí právo silnějšího. Vzkřriššní Evropy může být podle Hallera uskutečněno výlučně prostřednictvím sbratření všech států pod autoritou obecně uznané Prozrretelnosti. Př́ručka obecné politické vědy (Handbuch der allgemeinen Staatskunde, 1808) z něho učinila jednoho $\mathrm{z}$ nejznámějších odpůrců odkazu Francouzské revoluce. Poté, kdy v roce 1820 oznámil konverzi ke katolicismu, musel rezignovat na své profesorské místo. Odešel do Paříže, kde jej konzervativní panovník Karel X. zahrnul svou přízní. Po červencové revoluci roku 1830 se Haller natrvalo stáhl do švýcarského ústraní, kde až do své smrti o čtyřiadvacet let později neúnavně útočil na povahu a hodnoty moderní doby.

Karl Ludwig von Haller byl přesvědčen, že učení Jeana Jacquese Rousseaua, které podle jeho mínění způsobilo Francouzskou revoluci, bylo přirozeným důsledkem reformace. $\mathrm{Z}$ tohoto důvodu je možné obrodit Evropu výlučně prostřed-

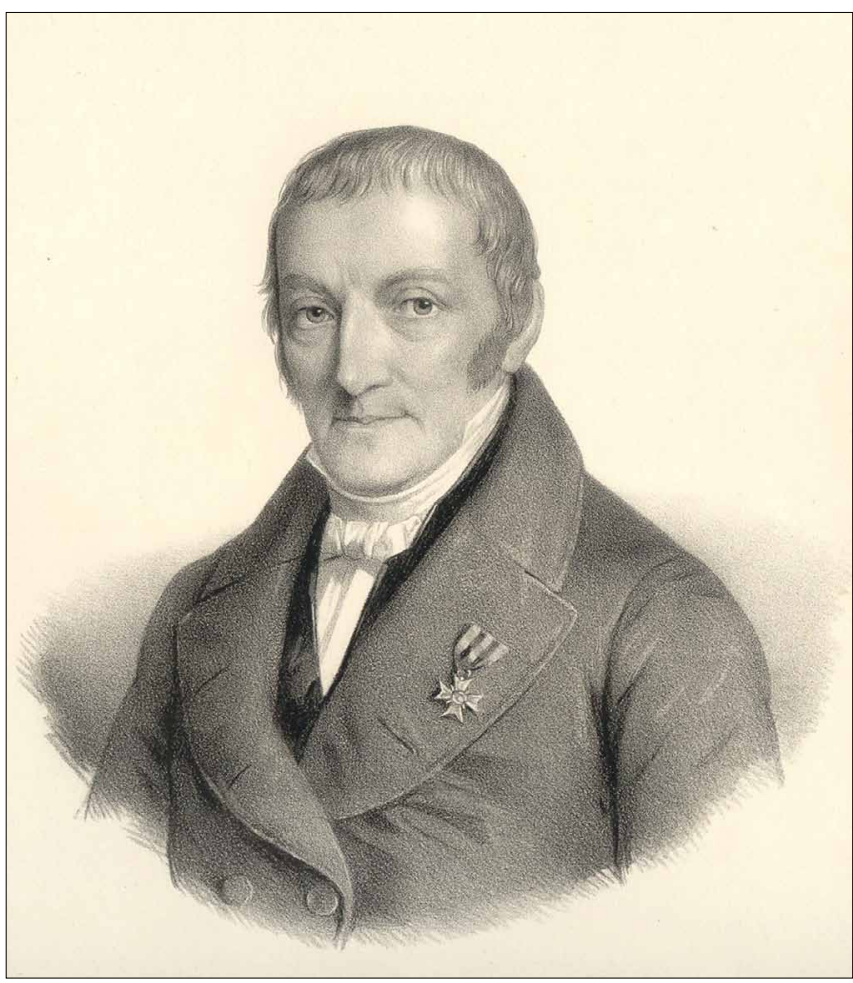

Obr. 4. Karl Ludwig von Haller. Zdroj: https://en.wikipedia.org/wiki/Karl_ Ludwig_von_Haller\#/media/File:KarlLudwigHaller.jpg

nictvím návratu ke katolicismu (Liedke 1958, 374-375). Vášnivým obhájcem a propagátorem Hallerových myšlenek byl Adam Müller, konzervativní patriot, jenž již v roce 1817 prohlásil, že Hallerova kniha by měla být $\mathrm{v}$ co největší míře šířena za podpory pruské vlády. Na univerzitách by měly být zřizovány speciální stolice určené výlučně pro výuku Hallerova učení. V Berlíně vznikl spolek Maikäferei, mezi jehož členy náleželi právník a veřejný činitel Ernst Ludwig von Gerlach, jeho bratr Leopold von Gerlach, hrabě Johann Peter Cajus zu Stolberg-Stolberg nebo ministr financí Albrecht von Alvensleben. Zmíněná skupina měla v duchu Hallerových idejí značný vliv na budoucího pruského krále Fridricha Viléma IV.

Na druhé straně vlivný pruský právník a historik Friedrich Carl von Savigny Hallera prakticky ignoroval (Liedke 1958, 376-377). Liberální básník a literát Achim von Arnim kritizoval Hallerův konzervativní katolický světonázor v románu Proměny společnosti (Metamorphosen der Gesellschaft) z roku 1823. Rovněž teolog a rektor Berlínské univerzity Friedrich Daniel Ernst Schleiermacher a filozof Georg Wilhelm Friedrich Hegel se postavili proti Hallerovi. Navzdory zmíněným výhradám se Hallerovo dílo stalo počátkem dvacátých let devatenáctého století prakticky jádrem pruské státní ideologie (Liedke 1958, 381). ${ }^{7}$

7 Haller byl nicméně kritizován i z konzervativních kruhů. Např́iklad pruský konzervativní patriot a profesor na univerzitě ve Vratislavi Heinrich Steffens vytkl v knize Karikaturen des Heiligsten (1818-1821) Hallerovy jeho důraz na právo silnějšího (Liedke 1958, $381)$. 


\section{OBDOBÍ MEZI REVOLUCEMI 1830 AŽ 1848}

Romanticky zaměření myslitelé jako Johann Joseph Görres, Friedrich Schlegel a Heinrich Steffens byli přesvědčeni, že Německo, respektive Prusko, je možno obrodit výlučně prostřednictvím obecného obratu $\mathrm{k}$ náboženské víře. Heinrich Steffens se domníval, že by touto revitalizující religiozitou mělo být luteránství, zatímco Friedrich Schlegel poté, kdy koketoval s východními náboženstvími, vzhlížel ke specifické verzi univerzálnímu katolicismu. Na jeho základě by se mělo pod záštitou papeže zrodit teokratické společenství evropských národů (Liedke 1958, 383). Schlegel propagoval své názory především v periodiku Deutsches Museum vycházejícím v letech 1811 až 1812 a časopise Concordia (1820 až 1823), do něhož přispíval i Karl Ludwig von Haller, Zacharias Werner a Franz von Baader.

Friedrich Schlegel měl blízko k Johannu Josephu Görresovi. Oba muži v mládí obdivovali Francouzskou revoluci, poté se přiklonili $\mathrm{k}$ romantickému kosmopolitismu, a nakonec skončili jako stoupenci německého patriotismu a ortodoxního katolicismu (Liedke 1958, 386). Ve spise Německo a revoluce (Teutschland und die Revolution) z roku 1819 Görres představil jako svůj ideál středověký korporativní stát složený ze tří sociálních vrstev tvořících celistvý politický organismus. Posláním státu je umožnit člověku, aby se prostřednictvím morálního a náboženského řádu povznesl nad vulgární materialismus. Přirozeným protějškem státu je církev, která je potřebná pro harmonický rozvoj společnosti (Liedke 1958, 387-388). ${ }^{8}$ Görresovo zaujetí pro politický katolicismus vyústil do konfliktu s pruskými luteránskými úřady. Johann Joseph Görres odolal vábení vídeňských konzervativních kruhů a usadil se na Mnichovské univerzitě. Periodika, která Görres řídil v Mnichově, Der Katholik, Eos a Historisch-politische Blätter für das katholische Deutschland, se stala důležitou platformou konzervativního katolicismu v Bavorsku. Ve zmíněných časopisech vycházely texty autorů, jako byl Edmund Burke, Karl Ludwig von Haller, Adam Müller, Friedrich Leopold Stolberg, Hugues Félicité Robert de Lamennais, Louis Gabriel de Bonald, Johann Georg Hamann nebo Karl Wilhelm Ferdinand Solger.

Červencová revoluce v roce 1830 a abdikace francouzského krále Karla X. znamenaly konec epochy restaurace. Poté bylo většině konzervativců zřejmé, že musí přistoupit na určitý kompromis se silami nastupující modernity. Výsledkem byl zrod řady různých hybridních ideologií, které ovlivňují politický život Západu prakticky dodnes. Mnozí autoři obávající se šíření „rozkladného“ liberalismu podlehli pesimismu a historickému fatalismu. Německý historik starověkého Říma Barthold Georg Niebuhr předvídal rok před svojí smrtí prríchod staletí barbarství. Revoluční radikalismus podle jeho mínění zničí západní civilizaci. Karl Ludwig von Haller věril, že i po historickém selhání Francie,

8 Adam Müller vyjádřil podobné teze v díle Von der Notwendigkeit einer theologischen Grundlage der gesamten Staatswissenschaften $\mathrm{z}$ roku 1819. která není schopna svými morálními silami obnovit ancien régime, se Evropa může navrátit $\mathrm{k}$ tradičním hodnotám a víre pod vedením pruského korunního prince Fridricha Viléma. Následník trůnu byl pokládán za reakcionáře. Sympatizoval s katolicismem a s nostalgií vzhlížel ke středověké společnosti. Poté, když nastoupil jako král Fridrich Vilém IV. na trůn, záhy narazil na realitu, jejíž povaha se vymykala jeho anachronické imaginaci. Uchýlil se k romantickým gestům bez skutečného politického dopadu. Rozhodl se např́klad obnovit gotickou katedrálu v Kolíně nad Rýnem, což Heinrich Heine ironicky komentoval ve skladbě Německo, zimní pohádka:

Vy bloudkové, spolku chrámový,

vy rukama slaboučkýma

dokončit chcete to pretrhlé

dílo, tu trucpevnost Řima!

V zemi probíhala industrializace, která vyhrocovala sociální vztahy. Král ponořený do snů o restauraci středověkého impéria to nicméně nevnímal.

V době, kdy Jacob Burckhardt přijel do Berlína, byl původní restaurační konzervatismus na ústupu a zdání vitality mu dodávala pouze podpora panovníka. Během semestru stráveného $\mathrm{v}$ Bonnu nacházejícím se $\mathrm{v}$ převážně katolickém Porýní, kde významná část vzdělanců odmítajících pruskou hegemonii náležela $\mathrm{k}$ liberálům, se Jacob Burckhardt sblížil s liberálním teologem a historikem Gottfriedem Kinkelem, který vyučoval církevní dějiny. Společně navštěvovali umělecký a básnický spolek Maikaferbund. Kinkel byl později aktivním účastníkem revoluce roku 1848, což byla jedna $\mathrm{z}$ prríčin ideové rozluky mezi oběma muži (Hinde 2000, 77-79).

V Bonnu se Jacob Burckhardt odklonil od Rankeho školy a zaměřil se na studium kulturních dějin. Tím se vyčlenil z hlavního proudu německé historiografie, který reprezentovali např́klad Heinrich von Treitschke nebo Heinrich von Sybel. Odpovídalo to jeho temperamentu. Na rozdíl od Leopolda von Rankeho se Burckhardt př́liš nezajímal o politické dějiny (Staatswissenschaft).

Po návratu do Berlína uvedl Gottfried Kinkel mladého studenta historie do proslulého salónu, který vedla Bettina von Arnim. Tato spisovatelka, autorka pamfletu Tato kniha náleži králi (Dies Buch gehört dem König, 1843), sestra Clemense Brentana, manželka básníka Achima von Arnim, švagrová ministra spravedlnosti Savignyho a celoživotní přítelkyně Johanna Wolfganga von Goetha, patřila k předním reprezentantům liberalismu v pruském hlavním městě. Zároveň však udržovala úzké vztahy s královskou rodinou. Mezi hosty jejího salónu nechyběl historik Friedrich Dahlmann nebo bratři Grimmové. Jacob Burckhardt se nikdy nestal liberálem. Nepřihlásil se však ani $\mathrm{k}$ pruskému etatistickému a militaristickému konzervatismu, který podle jeho mínění negarantoval žádné politické svobody. Burckhardt dával přednost tradičnímu měštanskému konzervatismu Basileje jako městského státu založeného na občanské samosprávě (Hinde 2000, 81).

$\mathrm{Na}$ jaře a v létě 1843 navštívil Jacob Burckhardt poprvé Paříž. Přivydělával si psaním článků pro Kolnische Zeitung.

9 Heine 1951, 145, přeložil Pavel Eisner. 
Naplno se projevil jeho konzervativní instinkt. Burckhardt kritizoval „balzakovskou“ Pařriž, v níž vládlo vrtošivé veřejné mínění a touha po penězích. Nenacházel porozumění ani pro nespoutanou svobodu tisku. Podle Burckhardta takové prostředí zcela ničí skutečnou uměleckou tvořivost a originalitu (Hinde 2000, 88). Burkchardtova kritika Berlína a Paříže odrážela jeho celoživotní odpor $\mathrm{k}$ centralismu, militarismu a masové demokracii „degenerující do radikalismu a socialismu. ${ }^{10}$ Již ve čtyřicátých letech devatenáctého století cítil, že $z$ této směsi mohou vzejít „noví Caesarové, více demagogičtí a nebezpečněǰ̌i než jejich starověké předlohy. Jeho ideálem byly „malé státy“ (Kleinstaat) typu svobodné Basileje, v nichž viděl záštitu opravdové svobody (Hinde 2000, 89). V tomto ohledu se názory Jacoba Burckhardta bližily myšlenkám Karla Ludwiga von Hallera.

V květnu 1843 obdržel Burckhardt doktorát filozofie na Basilejské univerzitě, kde začal přednášet. I když jeho vystoupení získala mezi studenty a širší veřejností značnou oblibu, místo soukromého docenta (Privatdozent) pro něj bylo v dané chvíli nedosažitelné. Působil devatenáct měsíců jako žurnalista v listu Basler Zeitung zastupujícím basilejské vládnoucí kruhy. Koncem března 1846 Jacob Burckhardt odjel do Říma. Jeho italský pobyt přerušilo pozvání od Franze Kuglera do Berlína, kde společně pracovali na Přehledu dějin malǐrství (Handbuch der Geschichte der Malerei). Koncem roku 1847 se Burckhar$\mathrm{dt}$ vrátil do Itálie, kde setrval šest měsícủ. $V$ té době vypuklo na severu Apeninského poloostrova povstání proti rakouské nadvládě. Jacob Burkhardt, který se opět věnoval politické žurnalistice, psal mezi listopadem a dubnem 1848 reportáže o nepokojích pro Basler Zeitung. ${ }^{11}$ Dramatické události v Itálii posílily Burckhardtovu nedůvěru $\mathrm{k}$ radikálnímu liberalismu a masové demokracii (Hinde 2000, 110). I když Jacob Burckhardt pozbyl původní náboženské víry, jeho konzervatismus do značné míry vyplýval $\mathrm{z}$ vědomí nedokonalosti lidské povahy, které zdědil z křestanské ortodoxie. Odmítal Rousseauovo učení o neposkvrněné lidské přirozenosti, již údajně zkorumpovaly až politické a ekonomické instituce. Vủči švýcarskému mysliteli nešetřil Burckhardt kritikou. Jean Jacques Rousseau byl podle jeho mínění „plebejec“, který postrádal skutečné porozumění pro reálný život a starosti běžného člověka a zůstal pouhým teoretikem a utopistou (Hinde 2000, 114-115).

Mezitím proběhla ve Švýcarsku v listopadu 1847 krátká občanská válka s dalekosáhlými důsledky. V roce 1845 založilo sedm katolických kantonů s konzervativní správou na obranu svých zájmů proti centralizačním snahám vlády spolek zvaný Sonderbund. Federální parlament (Tagsatzung) prohlásil v ř́ij-

10 V ř́inu 1846 došlo v Ženevě $\mathrm{k}$ politickému převratu, který Andreas Heusler, vlivný basilejský právník, politik a vydavatel listu Basler Zeitung, označil za projev sociálního radikalismu, vzporu proletariátu, ohrožující společenský řád v samotné Basileji. Jacob Burckhard obdobně jako Johann Jacob Bachofen plně sdílel jeho obavy ze socialistické revoluce (Hinde 2000, 48).

11 Z této doby také pocházejí jediné Burckhardtovy sbírky básní Ferien, Eine Herbstgabe a E Hampfeli Lieder (Hinde 2000, 31). nu 1847 Sonderbund za neústavní a nařídil jeho rozpuštění silou. Od 3. do 29. listopadu 1847 potřela federální armáda vedená generálem Guillaumem Henrim Dufourem katolické jednotky v několika srážkách, $\mathrm{v}$ nichž nepadlo více než sto mužů. V roce 1848 nová švýcarská federální ústava ukončila praktickou nezávislost kantonů a přeměnila Švýcarsko ve federální stát. Př́islušníci jezuitského řádu byli vypovězeni ze země. ${ }^{12}$ Výsledek konfliktu byl vnímán jako porážka konzervatismu a triumf liberalismu, který podnítil vlnu revolucí, jež v průběhu následujícího roku otřásly Evropou. V samotné Basileji si tradiční patricijská vrstva udržela moc až do roku 1875. Rovněž cechovní systém zůstal zachován. Konzervativní město vzdorovalo postupujícímu př́livu liberalismu, který měnil evropskou civilizaci v sekulární, rovnostárskou a demokratickou společnost (Hinde 2000, 112).

\section{BURCKHARDTU゚V KONZERVATISMUS A POLEMIKA S LIBERÁLNÍMI A DEMOKRATICKÝMI HODNOTAMI}

Nedostatek finančních prostředků přinutila Jacoba Burckhardta $\mathrm{v}$ roce 1855 přijmout místo profesora dějin umění na nově zř́izené polytechnice $\mathrm{v}$ Curychu. Filolog a historik Johann Jacob Bachofen později tvrdil, že to byl on, kdo př̀měl roku 1858 představitele basilejské univerzity, aby přesvědčili Burckhardta $\mathrm{k}$ návratu pod př́slibem zaměstnání vysokoškolského pedagoga. V roce 1871 Ernst Curtius nabídl Burckhardtovi jménem pruského ministerstva kultury prestižní pozici na Berlínské univerzitě, která se uvolnila po smrti Leopolda von Rankeho. Burckhardt odmítl.

Jacob Burckhardt byl přesvědčen, že německy hovořící populace ve stř̌ední Evropě, a to včetně Švýcarska, tvoří od středověku z kulturně historického hlediska společný celek (Kulturnation). Za svůj úkol pokládal „ukázat Švýcarům, že jsou Němci“. V politické sjednocení Německa na etnickém základě však nevěřil, pruské aspirace odmítal, odsuzoval Bismarckovy agresivní války a obdobně jako Haller upřednostňoval pluralitu malých německojazyčných států (Hinde 2000, 74-75). V Německu podle jeho mínění započal proces, který se vymkl kontrole a vede př́slušné společnosti do zkázy. Hohenzollernové si sami kopou hrob, protože tím, že zbavují moci místní panovníky, zpochybňují svoji vlastní legitimitu (Hinde 2000, 126). Se znepokojením sledoval vítězství Pruska nad Francií $\mathrm{v}$ roce 1871, které podle jeho mínění dovršilo militarizaci země (Hinde 2000, 136).

Revoluce $\mathrm{v}$ roce 1848 a pozdější vzestup pruské moci na úkor malých německých států přivedl Jacoba Burckhardta $\mathrm{k}$ historickému pesimismu a "únavě $\mathrm{z}$ moderního světa“. Jeho odpovědí bylo stažení se do „mnišského" ústraní, celoživotního studia historie, a především dějin umění. Burckhardtův historický pesimismus a skepticismus vůči modernitě nápadně kontrastovaly s entuziasmem berlínských historiků fascinovaných mocenským a ekonomickým vzestupem Pruska a Německa jako celku. Friedrich Meinecke to při-

12 Tento zákaz byl zrušen na základě referenda v květnu 1973. 
čítal Burckhardtově lpění na anachronismu provinční Basileje nacházející se mimo hlavní modernizační proudy německého života. Nacionalistický historik Heinrich von Treitschke nazval zmíněné město „zatvrzelým závětřím Evropy“ (Hinde 2000, 4-5).

$\mathrm{V}$ roce 1875 byla $\mathrm{v}$ Basileji zavedena nová federální ústava, podle níž připadlo volební právo nikoliv pouze basilejským měštanům, ale všem obyvatelům kantonu. Znamenalo to definitivní konec vlády patriciátu a počátek éry, kterou Jacob Burckhardt vnímal jako radikálně liberální. Basilej přestala být „svobodným městem“. Masová demokracie, socialismus, demagogie a despotismus vyvrátily brány šestisetleté basilejské republiky. Burckhardtův historický pesimismus se prohloubil (Hinde 2000, 129). Navzdory této skutečnosti se rozhodl strávit v Basileji celý život. Představovala pro něj přijatelnější útočiště než Bismarckovo Německo, jehož se děsil. Jacob Burckhardt byl typickým nositelem občanské ctnosti (Heimatsinn), s níž organicky spojoval svůj patriotismus. Občanská ctnost spočívala mimo jiné v respektu a úctě $\mathrm{k}$ „paměti místa“ zahrnující tradici, jazyk, historii a architekturu. Regionální kantonální identita (Kantonligeist) byla důležitou součástí politického života švýcarské konfederace a jedním z jejích stavebních kamenů. Švýcarští liberálové ji pokládali za výraz provinčního provincialismu, který brání národnímu sjednocení (Hinde 2000, 130-131). Burckhardt nicméně nedůvěřoval okázalým projevům švýcarské národní jednoty, $\mathrm{v}$ níž viděl manifestaci moderní masové kultury (Kulturfaulnis). Domníval se, že neexistuje skutečná náhrada za tradiční vzdělání (Bildung) a kulturu (Kultur). Právě dosažení vzdělání, a nikoliv štěstí, představovalo podle Burckhardta cíl a smysl života. Byl přesvědčen, že pouze skupina asketických jedinců dokáže obrodit národního ducha (Hinde 2000, 136). Jacob Burckhardt byl skeptický vůči myšlence pokroku. Odmítal tezi o morální zaostalosti nebo násilnictví starých dob a morálnímu vzestupu moderní éry: „Proto je domněnka, že žijeme ve věku mravního pokroku, krajně směšná, bereme-li $v$ úvahu riskantní doby, jejich svobodná síla ideální vưle ční vysokými věžemi několik set katedrál $k$ nebi. K tomu přistupuje naše nejapná nenávist proti všemu odlišnému, mnohotvárnému, proti symbolickým obřadìm a napolo nebo zcela spícím práviom, ztotožňování mravnosti s precizností a neschopnost chápat pestrost a nahodilost. To neznamená, že se na nám stýská po středověku, jde jen o porozumění. Naším životem je obchod, tehdejším bylo bytí; celý národ sotva existoval, ale lidovost vzkvétala" (Burckhardt 1995, 59). Mravní pokrok je pouhým zkrocením individua zbytnělou státní mocí. Mravnost je konstantní historickou veličinou a současný obyvatel západního velkoměsta nevyniká $\mathrm{v}$ tomto ohledu nad archaickým člověkem. Totéž lze říct o domnělém intelektuálním vzestupu. Lidé se vždy vyznačovali pokorou a úctou k odkazu předků. Nenapadlo by je se arogantně vyvyšovat nad morální a materiální výkonnost svých předchůdců. Teprve po Rousseauovi se lidé domnívají, že se nacházejí na vyšší mravní úrovni než dříve. Tato povýšenost a souzení minulosti má podle Burckhardta příčinu v pouhé nepřiznané skutečnosti, „že vydělávání peněz je dnes snazší a jistější než kdy předtím; až bude ohroženo, vymizí i toto sebevědomi" (Burckhardt 1995, 60). Z Burckhardtova konzervatismu vyplývala i jeho nedůvěra vůči moderní demokracii, kterou označil za „krajně různorodý světový názor, slepený z tisícerých různých zdrojů, vrstev a vyznavačů, který je však $v$ jednom směru di̊sledný: že totiž pro něj nemůže být moc státu nad jednotlivcem nikdy dost široká, takže stírá hranice mezi státem a společností, státu přisuzuje všechno to, co zř̀ejmè nebude chtít dělat společnost, avšak chce všechno udržet ve stavu diskuze a pohybu a posléze jednotlivým kastám priznává specifické právo na práci a materiální zabezpečeni" (Burckhardt 1995, 174).

Burckhardtův skepticismus vưči demokracii a modernitě se odrazil v jeho přednáškách o řeckých kulturních dějinách, ve kterých zdůraznil, že rozvoj racionální filozofie ohrozil působivost umění a mytologie. Po Euripidovi a Sofoklovi zmizela z řeckého kulturního života velká poezie. Zahubila ji demokracie a kritický rozum (Hinde 2000, 166). Obdobně jako Gobineauovi byl Burckhardtovi mnohem bližší Michelangelo, Rafael nebo Tizian než jeho současníci. Jeho druhou vlastí byla Itálie, „útočiště nostalgikư“, kam stejně jako jeho basilejský vrstevník Johann Jakob Bachofen navzdory svému odporu k cestování zajížděl. Burckhardtova kniha Der Cicerone sloužila jako oblíbený průvodce po pamětihodnostech Apeninského poloostrova. S výjimkou návštěv Itálie a občasných soukromých cest, které jej dvakrát přivedly do Prahy, Jacob Burckhardt neopouštěl Basilej. Držel si odstup od akademického světa. Žil skromně jako svobodný mládenec. Oblečen $\mathrm{v}$ nenápadném černém oděvu a předčasně bílými vlasy připomínal spíše pastora než vysokoškolského profesora (Herman 1997, 81). Burckhardtův žák Johan Huizinga jej nazval „nejmoudřejším z Evropanů“ (Burckhardt 1995, 237). Jeho posluchač a kolega na univerzitě v Basileji profesor klasické filologie Friedrich Nietzsche jej obdivoval. Často mu psal a usiloval o jeho uznání, na které byl ovšem Jacob Burckhardt skoupý. Stejně jako Arthur Gobineau, Alexis de Tocqueville a mnozí další myslitelé se Jacob Burckhardt snažil začlenit události roku 1848 do kontextu evropských dějin. Dílo Starý režim a revoluce od Alexise de Tocquevilla četl Burckhardt velmi pečlivě. Ve svých vlastních spisech citoval zmíněného francouzského liberála dosti často. Souhlasil s Tocquevillovou tezí, že francouzský revoluční systém po roce 1789 navázal na dlouhodobý vývoj ancien régime. Jacob Burckhardt učinil nezávisle na Tocquevillovi podobný postřeh $\mathrm{v}$ přednášce o „ére Fridricha Velkého“ v roce 1852, kdy vyšla Tocquevillova kniha. ${ }^{13}$ Burckhardt současně považoval - poněkud paradoxně - Francouzskou revoluci za zásadní zlom, porušení kontinuity v dějinách Západu, po němž byla jakákoliv restaurace nemožná. Svému př́teli Gottfriedu Kinkelovi v roce 1842 napsal, že devatenácté století začalo jako skutečný nový začátek, tabula rasa (Hinde 2000, 11).

Jacob Burckhardt byl skeptický vůči fantaziím o revitalizační úloze barbarů, které Gobineau nebo Lasaulx čerpali mimo jiné z Vicova nebo Gibbonova díla (Herman 1997, 81).

13 Stejnou myšlenku vyslovil ve studii Vorlesungen über die Freiheitskriege z roku 1846 Johann Gustav Droysen (Kahan 1992, 6). 
Burckhardt byl přesvědčen, že role barbarů v dějinách se přeceňuje. Ve své studii Věk Konstantina Velikého (Die Zeit des Konstantin des Großen) vydané v roce 1853 Jacob Burckhardt argumentoval, že zhroucení Rímské říše byla způsobeno nadměrnou expanzí imperiálních struktur na úkor jiných životně důležitých sociálních institucí. Barbaři hráli údajně ve zmíněném procesu pouze podružnou úlohu. Diskreditace státu uvolnila cestu ke vzestupu katolické církve, jejíž excesy vedly k reformaci a nástupu národního státu jako hlavní politické struktury moderního Západu (Herman 1997, 82-83).

Jacob Burckhardt rozpoznal množství analogií mezi soumrakem starověku a domnělou kulturní krizí, již prodělávala $\mathrm{v}$ polovině devatenáctého století západní společnost. Za jednu z destruktivních sil rozvracejících Západ pokládal Jacob Burckhardt demokracii, produkt Francouzské revoluce, který učinil lid jediným legitimním zdrojem politické moci. Výsledkem byl vzestup radikalismu a utopická snaha přebudovat celou společenskou stavbu ve jménu reforem a pokroku. Vlivné průmyslové kruhy splynou se státem a široké masy budou hledat záštitu a ochranu v demagogických vůdcích, které pejorativně nazýval terrible simplificateurs („strašliví zjednodušovatelé). Burckhardt proto pokládal Napoleona III. za archetypální ztělesnění vládců budoucnosti (Herman 1997, 83). Na rozdíl od Platóna a Aristotela, kteří považovali transformaci demokracie v diktaturu za neodvratitelný proces, Jacob Burckhardt podtrhl nástup masové společnosti, který vyhrotí despotický ráz režimu. Společnost se tak změní v obrovskou disciplinovanou a nesvobodnou „vojenskou továrnu“. Pokud pomineme méně konkrétní narážky Alexise de Tocquevilla v jeho knize Demokracie v Americe, byl Jacob Burckhardt prvním západním autorem, který varoval před moderním totalitarismem (Herman 1997, 84): „Všechny pozdější knižzy o duši davů, vzpourách davů a osamělém davu navazují na tato Burckhardtova pozorováni" (Burckhardt 1995, 240).

\section{BURCKHARDTOVO VYMEZENÍ KULTURY}

Kultura renesance $v$ Itálii (Die Kultur der Renaissance in Italien) vydaná v roce 1867 je bezpochyby nejznámější Burckhardtovou knihou, která mu zajistila mezinárodní proslulost. Romantismus počátku devatenáctého století se vyznačoval kultem středověku, jehož populárním žánrovým produktem byl gotický román. Ve druhé polovině se perspektiva proměnila. Západní Evropa procházející hospodářským rozmachem se vzhlížela více $\mathrm{v}$ podnikatelsky agilních městech renesanční Itálie než ve středověké mystice (Burckhardt 1996, 242-243). Burckhardta přitahovala k Itálii čtrnáctého až šestnáctého století údajná podobnost mezi Basilejí, v níž jako v malém státě (Kleinstaat) může lid (Kulturvolk) udržet na rozdíl od impérií svoji svobodu, a renesančními městskými státy typu Florencie, jež zase navázala na tradici polis ve starověkém Řecku (Hinde 2000, 128).

Jacob Burckhardt nicméně nenáležel mezi nekritické zastánce renesance. Obdivoval organickou jednotu středověkých duchovních komunit. Renesance pro něho znamenala obrat k demonstraci čisté síly, která se vymkla jakémukoliv morálnímu kontextu neboli, jak prohlásil spisovatel Hermann Broch, renesance byla dobou zločinnou. Arthur Gobineau viděl v symbióze Michelangelova uměleckého génia a Machiavelliho realistického cynismu doklad historické velikosti. Papeži Alexandru VI. vložil do úst následující slova: „Jdi rovně vpřed. Čin to, co se ti líbí pouze na tolik, pokud ti to prospívá. Ponech malým duchưm, láji podřizených, ochablosti a úzkostlivosti" (Gobineau 1925, 68). Podobný př́stup byl ovšem pro Buckhardta, který byl obdobně jako Alexis de Tocqueville př́liš spjat $s$ moralizujícím étosem, nepř́ípustný (Herman 1997, 86).

Po Kultuře renesance $v$ Itálii se Burckhardt věnoval výlučně přednáškové činnosti. V roce 1892 odešel na odpočinek. Zesnul o pět let později v srpnu 1897. Úvahy o světových dějinách Jacoba Burckhardta byly zpětně vyzvedávány jako „prorocká diagnostika krizí, před kterými bude stát moderní svět " (Burckhardt 1995, 235). Rukopis zmíněné knihy připravoval Jacob Burkchardt pod názvem Über geschichtliches Studium jako podklady pro své přednášky od roku 1868. Burckhardt text nikdy nevydal. Publikoval jej až po jeho smrti v roce 1905 Burckhardtův synovec Johann Jakob Oeri jako Weltgeschichtliche Betrachtungen. ${ }^{14} \mathrm{~V}$ kontextu probíhajícího sporu o kulturní dějiny Karla Lamprechta mezi německými historiky ${ }^{15}$ Friedrich Meinecke vyslovil obdiv pro Burckhardtův záběr a aspirace, na druhé straně ale zdůraznil, že jeho metoda se rozchází s tradicí německého historicismu (Hinde 2000, 4). Jacob Burckhardt měl obdobně jako Giambattista Vico nebo Ernst von Lasaulx pochopení pro cyklické pojetí dějin. Domníval se, že mezi určitými historickými epochami lze nalézt nápadné historické analogie, např́klad mezi renesanční a moderní dobou. Jacob Burckhardt tak měl skutečně blíže k Oswaldu Spenglerovi a Arnoldu Toynbeemu než pozitivistickým historiografưm své éry. Tato skutečnost částečně vysvětluje Meineckovu kritiku, Burckhardtovu intelektuální zdrženlivost a jeho částečné stažení do ústraní.

Jacob Burckhardt rozlišoval tři hlavní „historické potence“ (Potenzen), které zahrnují stát, náboženství a kulturu. Stát a náboženství představují univerzální fenomén, jenž je výrazem politické a metafyzické potřeby. Naproti tomu kultura představuje lokální materiální a duchovní souhrn sociálního života, techniky, umění, básnictví a věd. Zdá se, že se dưraz na stát, kulturu a náboženství se v dějinách mění. Existují epochy skoro výlučně politické nebo náboženské či doby vyznačující se značným kulturním rozmachem (Burckhardt 1995, 26-27). Specifická kombinace či vzájemné vztahy mezi

14 V angličtině vyšla kniha původně v roce 1943 pod názvem Force and Freedom: Reflections on History, $\mathrm{v}$ roce 1979 pod zkráceným označením Reflections on History.

15 Karl Lamprecht vydal v letech 1891 až 1909 Déjiny Německa (Deutsche Geschichte), v nichž především pod vlivem Wilhelma Wundta zdůraznil zásadní význam psychologicky podmíněných kulturních cyklů na politické a hospodářské dějiny. Proti Lamprechtovi se postavili zejména badatelé navazující na odkaz Leopolda von Rankeho, např́klad Max Lenz, Felix Rechfahl, Max Weber nebo Georg von Below (viz Lamprecht 1905). 
dílčími historickými potencemi vytváři svéráznou konfiguraci charakteristickou pro danou historickou epochu, její konflikty, výzvy a úděl.

Primárním účelem státu, první ze zmíněných potencí, je podle Burckhardta v podstatě „zotročení podrobených“ (Burckhardt 1995, 30). Stát je sice „zástavou práva a dobra“, ale ničím více. Snahu o uskutečnění mravnosti na zemi prostřednictvím státu pokládal Jacob Burckhardt za iluzi, která musí ztroskotat na nedokonalosti lidských bytostí. Zásluhou státu je vynucování koexistence různých, často protikladných náboženství a zabránění tomu, aby se „různé metafyziky“ navzájem krvavě nepotíraly (Burckhardt 1995, 30). Stát nicméně jako nositel moci je potenciálně nebezpečný, protože „moc sama o sobě je vždycky zlá, at ji vykonává kdokoli. Není to setrvávání na něčem, nýbrž chtivost a tím je eo ipso nenasytná, proto je sama neštastná a musí tedy přivádět do neštěstí i druhé (Burckhardt 1995, 86). Čím více stát ztrácí svého tradičního posvátného práva nad životem a majetkem, tím více se rozšiřuje jeho profánní moc (Burckhardt 1995, 120).

Náboženství zbavilo primitivního člověka strachu, jak prohlásil Ernest Renan „první na světě vytvořil bohy strach.“ Je výrazem trvalé metafyzické potřeby člověka: „Jeho velikost spočívá v tom, že predstavuje celé nadsmyslné doplnění člově$k a$, všechno to, co si sám není s to dát. Zároveñ je odrazem celých národi̊ a kulturních epoch do čehosi velkého Jiného nebo: otisk a obrys, který vtahuji do Nekonečna" (Burckhardt 1995, 36-37). Jacob Burckhardt rozlišil náboženství národní a světová, přičemž národní náboženství, která jsou starší, mohou být, např́íklad u Řeků a Rímanů, polyteisticky přívětivá, pohostinná i otevřená vůči jiným božstvům, jindy jako u Peršanů arogantní a agresivní. Světová náboženství, buddhismus, křestanství nebo islám, reprezentují především sociální hnutí relativizující národní příslušnost (Burckhardt 1995, 44). Burckhardt identifikoval primární stádium originální víry označované jako naivní, sekundární stádium, během něhož se víra stala tradicí, a terciárním stádium, kdy se religiozita opírá především o svoji starobylost a sepětí s národní identitou. V některých př́ípadech není zřejmé, zda ještě jde o skutečné náboženství či spíše o rituál splývající s politikařením. Vnější podoba náboženství může přežít dlouho poté, kdy je samotná víra mrtvá. Některé pasáže z Burckhardta nápadně připomínají Spenglerovo dílo: „Každé náboženství zakládá dosti brzo posvátné právo, tj. prolíná se těsně s celým veřejným stavem, jehož je zárukou, nebo zakládá svou hierarchii mimo rámec států, ale $v$ politickém vztahu $k$ nim. Tato jeho vnějši zařizení se úzce prolínají se vším materiálním a oprená o masy a jejich zvyky mohou navenek takové náboženství nekonečně dlouho uchovat tak, jako staré stromy, vnitřně zcela ztrouchnivělé, žijí ze své kưry a listů, a ještě s tím nadělají hodně parády; duch však $z$ něho už dávno vymizel a zatím ještě nevlastní nový, vědomý prvek metafyzický, na kterém by mohl vybudovat nové, protichůdné náboženství schopné boje a vítězství" (Burckhardt 1995, 46).

Náboženství je expanzionistické, jestliže by mělo takovou možnost, podmanilo by si zcela stát i kulturu a vytvořilo by celou společnost podle svého obrazu. $\mathrm{K}$ tomu došlo podle Burckhardta $\mathrm{v}$ př́ípadě islámu, který ovládl celou kulturu a zavedl despotický teokratický model státu (Burckhardt 1995, 88-89): „Kdo nedokáže - nebo ani nechce - muslimy vyhladit, měl by je nechat na pokoji; snad je možno jim vzít jejich pusté a vymrskané zemé, ale není možno vynutit si jejich skutečnou poslušnost vi̊či státu, který nevyznává korán. Jejich stř́dmost jim zajištuje vysoký stupeň individuální nezávislosti, otrokářství a vláda nad nevěrícími v nich udržuje pohrdání pracís výjimkou zemědělstvi" (Burckhardt 1995, 101).

Kulturu vymezil Jacob Burckhardt jako „celý souhrn projevư duchovního vývoje, které se odehrávají živelně a nečiní si nárok na univerzální nebo povinnou platnost" (Burckhardt 1995, 52). Kultura neustále mění nebo rozkládá stát a náboženství, případně je zcela ovládá a přizpůsobuje svým účelům. Poskytuje také trvalou kritickou platformu obou institucí a dokáže demonstrovat, kdy v nich forma a obsah již nejsou ve vzájemné shodě. Za dovršení vývoje každé kultury pokládal Burckhardt v Herderově duchu jazyk: „Jazyky jsou nejbezprostřednějším, nejvyšším projevem ducha národů, jeho ideální podobou, do které národy ukládají substanci svého duchovního života, zejména $v$ dílech velkých myslitelů a básníkü“ (Burckhardt 1995, 53). Specifickou oblastí kultury je umění, které Jacob Burckhardt považoval za záhadnější než vědu, která poznává to, co by existovalo i bez jejího přičinění. Umění ale zobrazuje vyšší život, který by bez něj nemohl existovat (Burckhardt 1995, 55). Obdobně jako Arthur Schopenhauer byl Burckhardt přesvědčen, že poezie je větším přínosem pro poznání podstaty lidstva než historie: „Poezie je pro historickou úvahu obrazem toho, co je v národech věčné" (Burckhardt 1995, 63).

Jacob Burckhardt nebyl pacifistou: „Národ si uvědomí svou skutečnou národní sílu jedině za války tím, že ji změř́ v boji s jinými národy ... Dlouhotrvající mír má za následek nejen neurotizaci, ale dává vznikat i spoustě žalostných, ustrašených nouzových existencí, které by bez něho nebyly možné a které se paks velkým pokřikem o svém, právu'přece nějak udržují nad vodou, ubirají pravým silám místo a zhuštují vzduch, vcelku pak také znešvařují výkvět národa. Válka dovádí ke cti opravdové síly; alespoň umlčí nouzové existence... Jedině válka skýtá člověku velkolepý pohled na všeobecné podřizení obecného blahu“ (Burckhardt 1995, 143-144).

Jacob Burckhardt, když žil jako poloviční poustevník v Basileji, měl jednoho oddaného obdivovatele. Čtyřriadvacetiletý Friedrich Nietzsche přijel do Basileje vlakem z Berlína 19. dubna 1869. Nietzsche, který ztratil víru v křestanského boha během studií na univerzitě v Bonnu, se zaměřil na klasickou filologii. Doktorát obhájil v Lipsku. Švýcarská Basilej byla jeho prvním akademickým postem. Mezi Burckhardtem a Nietzschem byl věkový rozdíl třiceti let, přesto se oba muži úzce sblížili. Jejich vztah nebyl pochopitelně zcela symetrický. Připomínal paternalistický poměr mezi Tocquevillem a Gobineauem. Friedrich Nietzsche docházel na Burckhardtovy přednášky o moderních dějinách a oba myslitelé plánovali napsat společnou knihu o kultuře starověkého Řecka (Herman 1997, 88). K tomu však nikdy nedošlo. 


\section{ZÁVĚR}

Antropologické vědy se plně emancipovaly a akademicky institucionalizovaly $\mathrm{v}$ anglosaském světě $\mathrm{v}$ závěrečných desetiletích devatenáctého století prostřednictvím představitelů klasického evolucionismu Edwarda Burnetta Tylora, Johna Lubbocka nebo Lewise Henryho Morgana. Pojem kultury jako klíčového nástroje studia a porozumění lidské odlišnosti a rozmanitosti jim umožnil vzdálit západní antropologické a historické myšlení od rasového konceptu (Budil 2003, 132156; 2007, 492-531). Zmínění autoři intelektuálně navazovali na odkaz představitelů skotského osvícenství, Adama Fergusona, Johna Millara nebo Williama Robertsona, kteř́ chápali dějiny lidstva jako progresivní sled univerzálních fází směřujících k dosažení nejvy̌šího morálního a materiálního stádia v podobě civilizace (Budil 2003, 85-89). Vủči této kombinaci skotského osvícenského progresivismu a antropologické instrumentalizace kultury lze nicméně postavit původní německé vymezení pojmu kultury, které je spjato s konzervativní reakcí na osvícenství a jež je bližší současným antropologickým a historickým vědám, které se oprostily od etnocentrického a ideologicky zatíženého pojetí univerzálního pokroku zosobněného západní civilizací. Tuto interpretaci kultury odrážející konzervativní historický pesimismus a obavy z dalšího vývoje západní společnosti lze ukázat na osobě a díle velkého švýcarského historika Jacoba Burckhardta. I když Jacob Burckhardt zůstává znám téměř výlučně díky své knize Kultura renesance $v$ Itálii, a to $\mathrm{v}$ relativně úzkém okruhu zájemců o renesanci, jeho odkaz přetrval ve vlivné filozofii Friedricha Nietzscheho. Burckhardtovo humanistické, ale skeptické vymezení vůči modernímu progresivismu je inspirativní nejenom pro současné antropologické vědy, ale také pro všechny, kteří si uvědomují meze současného liberalismu, jenž pravděpodobně dospěl na limity svých historických možností.

\section{LITERATURA}

Budil, Ivo (2003): Mýtus, jazyk a kulturní antropologie. Praha: Triton.

Budil, Ivo (2007): Za obzor Západu. Praha: Triton.

Burckhardt, Jacob (1996): Úvahy o světových dějinách. Praha: Votobia.

Burckhardt, Jacob (2013): Kultura renesance v Itálii. Praha: Rybka Publishers.

Engel-Janosi, Friedrich (1953): The Historical Thought of Ernst von Lasaulx. Theological Studies 14(9): 377-401.

Gombrich, Ernst H. (1969): In Search of Cultural History. Oxford: Clarendon Press.

Heine, Heinrich (1951): Výbor z díla II. Praha: Svoboda

Herman, Arthur (1997): The Idea of Decline in Western History. New York: The Free Press.

Herman, Arthur (2001): The Scottish Enlightenment: The Scots' Invention of the Modern World. London: Fourth Estate.

Kahan, Alan S. (1992): Aristocratic liberalism: The Social and Political Thought of Jacob Burckhardt, John Stuart Mill, and Alexis de Tocqueville. New York: Oxford University Press.

Lamprecht, Karl (1905): What is History? New York: MacMillan Company.

Liedke, Herbert R. (1958): The German Romanticists and Karl Ludwig von Haller's Doctrines of European Restoration. The Journal of English and Germanic Philology 57(3):371-393.

Herman, Arthur (1997): The Idea of Decline in Western History. New York: The Free Press.

Hinde, John R. (2000): Jacob Burckhardt and the Crisis of Modernity. Montreal \& Kingston: McGill-Queens University.

Sax, Benjamin C. (1992): Jacob Burckhardt and national history. History of European Ideas 15(4-6): 845-850.

Seymour, Bruce (1996): Lola Montez, a Life. New Haven: Yale University Press.Tonsor, Stephen J. (1964): The Historical Morphology of Ernst Von Lasaulx. Journal of the History of Ideas 25 (3): 374-392. 